\title{
Study on ambient air quality in Beijing for the summer 2008 Olympic Games
}

\author{
Wen-xing Wang • Fa-he Chai $\cdot$ Kai Zhang • \\ Shu-lan Wang • Yi-zhen Chen • Xue-zhong Wang • \\ Ya-qin Yang
}

Received: 22 January 2008 / Accepted: 26 February 2008 /Published online: 30 April 2008

(C) Springer Science + Business Media B.V. 2008

\begin{abstract}
With the coming/approaching of the Olympic Games in 2008, air pollution in Beijing attracts the attention of government and people. The objective of this study is to define the air quality during the Olympic Games; we conducted the observation of $\mathrm{SO}_{2}, \mathrm{NO}, \mathrm{CO}, \mathrm{NO}_{2}, \mathrm{O}_{3}$, and $\mathrm{PM}_{10}$ from August 7 to September 30 in 2007 in Beijing. The results showed that the average daily concentrations of $\mathrm{SO}_{2}, \mathrm{NO}_{2}, \mathrm{CO}$, and $\mathrm{PM}_{10}$ during observation were 0.024 , $0.072,2.25$, and $0.19 \mathrm{mg} \mathrm{m}^{-3}$, respectively. Compared with the National Ambient Air Quality Standard II, the concentrations of $\mathrm{SO}_{2}$ and $\mathrm{CO}$ in the observation were low, the concentration of $\mathrm{NO}_{2}$ basically satisfied the National Ambient Air Quality Standard II, and the concentrations of $\mathrm{O}_{3}$ and $\mathrm{PM}_{10}$ were much higher than the values of the standard. The characteristics of diurnal variation of NO, $\mathrm{NO}_{2}, \mathrm{CO}$, and $\mathrm{PM}_{10}$ were similar, and the lower concentrations of these pollutants were observed by day and the higher concentrations at night. The concentration of $\mathrm{SO}_{2}$ in the daytime was a little higher than that at night. The highest 1-h concentration of $\mathrm{O}_{3}$ occurred at 14:00 local time.
\end{abstract}

Keywords Beijing $\cdot$ Air quality Pollution characteristic

W.-x. Wang $(\varangle) \cdot$ F.-h. Chai $\cdot$ K. Zhang $\cdot$ S.-1. Wang $\cdot$

Y.-z. Chen $\cdot$ X.-z. Wang

Chinese Research Academy of Environmental Sciences,

Beijing 100012, China

e-mail: wxwang99@hotmail.com

Y.-q. Yang

Key Lab of Marine Environmental Science and Ecology Ministry

of Education, Ocean University of China,

Qingdao 266100, China

\section{Introduction}

Beijing (39.13-41.08 $\left.\mathrm{N}, 115.22-117.50^{\circ} \mathrm{E}\right)$, the capital and a major metropolis of the People's Republic of China, is located in the north of Huabei (North China) Plain and is a part of the North Temperate Zone. Since the 1980s, the rapid industrial development and urbanization and rapid increasing traffic have resulted in severe air pollution in Beijing, especially particulate pollution (Zhang et al. 2000; He et al. 2001; Yao et al. 2003). Primary particles from coal combustion and vehicle emission with the secondary fine particle resulted in a complex particulate pollutant mixture (Lun et al. 2003; Shrestha et al. 2005; Sun et al. 2004). Pollutants come not only from local emissions but also from surrounding regional/background sources (An et al. 2007). For example, sandstorms often occurred, which intensified the particulate pollution in Beijing during the springtime (Song et al. 2006). Power plants are also significant sources of sulfur dioxide $\left(\mathrm{SO}_{2}\right)$ and nitrogen oxides $\left(\mathrm{NO}_{x}\right)$, which are harmful at high concentrations and contribute to the formation of atmospheric fine particles. $\mathrm{SO}_{2}$ and $\mathrm{NO}_{x}$ can be oxidized in the atmosphere to $\mathrm{SO}_{4}^{2-}$ and $\mathrm{NO}_{3}^{-}$and remain in the air for a long time (Vesilind 1982). The ambient concentrations of $\mathrm{NO}_{x}$ and particles were very high due to the rapid growth of the vehicles in Beijing (Jraiw 2002; Shrestha et al. 2005). It has been estimated that the transport sector was responsible for about $74 \%$ of $\mathrm{NO}_{x}$ emission in Beijing in 2007 (http://www.bjee. org.cn/news/index.php?ID=1483).

The ambient air quality for particle matter in National Ambient Air Quality Standard includes only $\mathrm{PM}_{10}$, not $\mathrm{PM}_{2.5}$. The annual average concentrations of $\mathrm{PM}_{10}$ ranged between 0.14 and $0.165 \mathrm{mg} \mathrm{m}^{-3}$ and the annual average concentrations of $\mathrm{PM}_{2.5}$ about $0.1 \mathrm{mg} \mathrm{m}^{-3}$, which accounted for about $60 \%$ of $\mathrm{PM}_{10}$ mass concentrations in 
Beijing (He et al. 2001). The scientific conditions' research on particulates especially fine particulates has been conducted including sources (Sun et al. 2004), size distribution (John et al. 1990; Zhang et al. 2000), chemical compositions (Lun et al. 2003; Yao et al. 2002, 2003), visibility (He et al. 2001; Okuda et al. 2004), and their impacts on human health (Zhang et al. 2000). Okuda et al. (2004) and He et al. (2001) found that organic components, secondary aerosol, soilderived particles, and coal combustion were primary contributors to $\mathrm{PM}_{10}$ in Beijing. Zhang et al. (2007) analyzed nitrate, sulfate, and ammonium in the polluted atmosphere of Beijing and found that the mean concentration of watersoluble ions increased during heavily polluted atmospheric conditions.

There have been few studies analyzing the air quality in summer in Beijing at present. To discuss the potential air quality during the Olympic Games in Beijing in 2008, selected atmospheric pollutants were measured continuously during this period in 2007 when the Para-Olympic Games were held. Thus, analysis of air pollution characteristics during this time period can provide valuable guidance in developing control plans on air quality for the 2008 Summer Olympic Games.

\section{Materials and methods}

\section{Experimental site and period}

The sampling instruments were installed on the roof of a $15-\mathrm{m}$ building of the Chinese Research Academy of Environmental Sciences. The building is located near a residential area in the north part of Beijing $\left(40^{\circ} 02^{\prime} \mathrm{N}, 116^{\circ} 24^{\prime} \mathrm{E}\right)$ outside the fifth ring roads of the city (Fig. 1). The distance from the sampling site to the 2008 Olympic Games' stadiums is only $5.7 \mathrm{~km}$ and to the Olympic village is less than $3 \mathrm{~km}$. The sampling results potentially represent air quality levels in the vicinity of the Olympic venues as there are no industrial air pollution sources nearby. Continuous measurements of the gaseous pollutants were conducted during the period August 7 to September 30, 2007 inclusive, whereas that of continuous $\mathrm{PM}_{10}$ measurements were collected for the period August 17 to September 30, 2007.

\section{Monitoring methods}

The concentration of $\mathrm{SO}_{2}$ was measured using the highdensity impulse fluorescence reaction (Thermo Fisher Model 43i Trace Level), $\mathrm{NO}-\mathrm{NO}_{2}-\mathrm{NO}_{x}$ concentrations were measured using the chemiluminescent reaction (Thermo Fisher Model 42i Trace Level), CO using the gas filter correlation reaction (Thermo Fisher Model $48 \mathrm{i}$ Trace Level), $\mathrm{O}_{3}$ using the UV photometric reaction, and $\mathrm{PM}_{10}$ using $\beta$-ray method (Thermo Fisher Model FH62C14) made by Thermo Fisher Environmental Instrument, USA. The sampling frequency was $1 \mathrm{~min}$.

\section{Experiment quality assurance and quality control}

Quality assurance and quality control were strictly adhered to during the measurement period. Constant temperature and humidity were maintained. Calibrations of equipments were done before and after the study period with automatic zeroing at midnight, and every 2 weeks, manual calibrations were performed. Invalid data were eliminated.

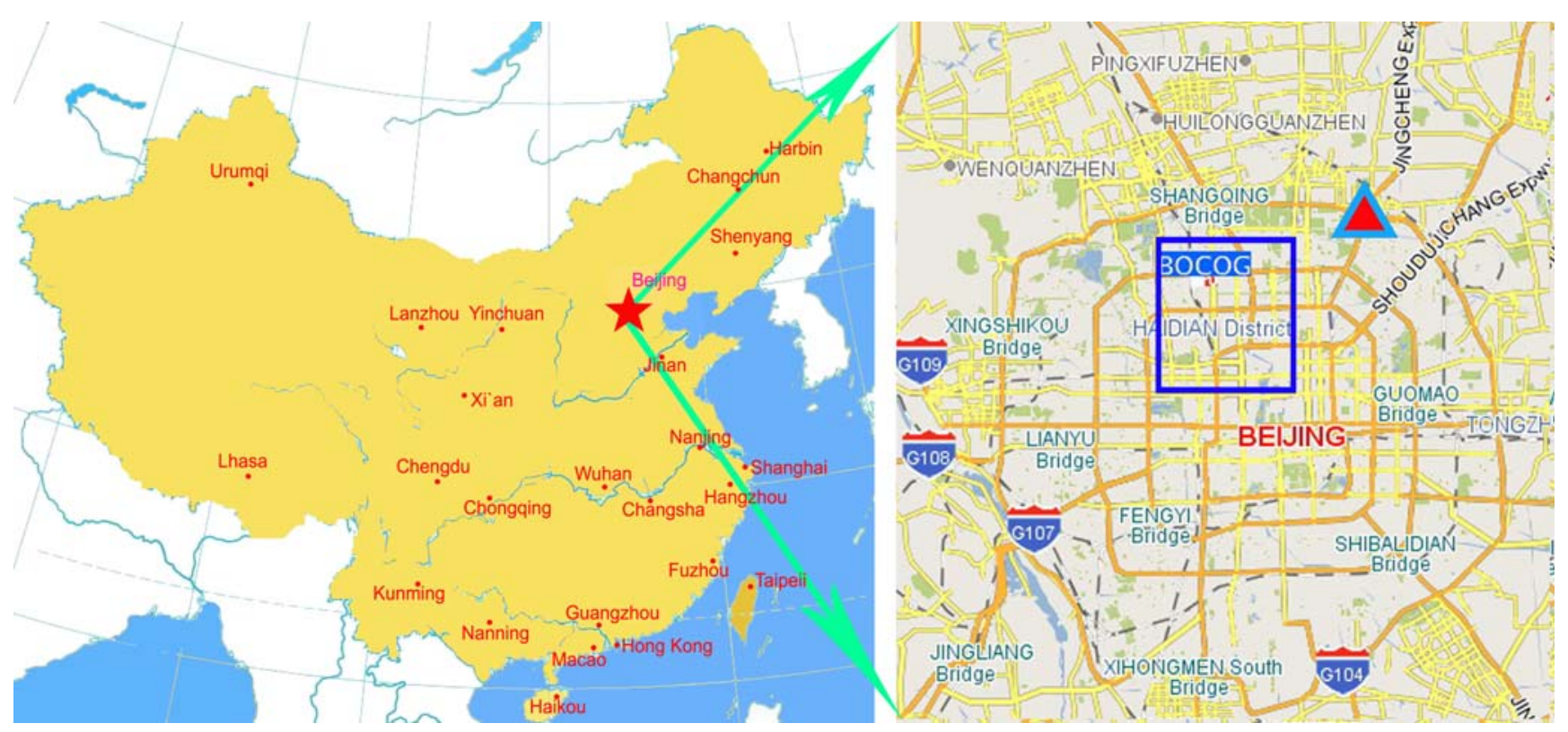

Fig. 1 Map showing Beijing city and the sampling site. (triangles, the sampling site; area boxed, The Olympic Games' stadiums) 


\section{Results and discussions}

Characteristics of pollutant concentrations

The daily average concentrations of $\mathrm{SO}_{2}, \mathrm{NO}_{x}, \mathrm{CO}, \mathrm{O}_{3}$, and $\mathrm{PM}_{10}$ were measured during the summer period August 7 to September 30, 2007. The daily average concentration of $\mathrm{SO}_{2}$ was $0.024 \mathrm{mg} \mathrm{m}^{-3}$ with the range of $0.01 \times 0.07 \mathrm{mg} \mathrm{m}^{-3}$ (Fig. 2), lower than the National Ambient Air Quality Standard II (Table 1), and close to the observation of Zhang et al. (2004) in October 1999 but higher than that in July 1999. The concentrations of $\mathrm{SO}_{2}$ were strongly affected by weather conditions (Yan and Huang 2002) and varied distinctively with seasons. The concentrations of $\mathrm{SO}_{2}$ were higher in winter (heating period) because of the burning of high-sulfur coal (Zhang et al. 2004) and lower in summer than other seasons. The daily average concentration of $\mathrm{NO}_{2}$ was $0.072 \mathrm{mg} \mathrm{m}^{-3}$ with the range of $0.03 \times 0.12 \mathrm{mg} \mathrm{m}^{-3}$, lower than the National Ambient Air Quality Standard II except on 1 day. The daily average concentration of $\mathrm{CO}$ was $2.25 \mathrm{mg} \mathrm{m}^{-3}$ with the range of $0.72 \times 3.46 \mathrm{mg} \mathrm{m}^{-3}$, which was lower than the National Ambient Air Quality Standard II and close to the observation of Xue et al. (2006) during the nonheating period. The hourly average concentration exceeding the National Ambient Air Quality Standard II of $\mathrm{O}_{3}$ happened on 30 days, and the unattainment rate was $54.5 \%$. The daily average concentration of $\mathrm{PM}_{10}$ was high $\left(0.19 \mathrm{mg} \mathrm{m}^{-3}\right)$ with a wide range of $0.04 \times 0.34 \mathrm{mg} \mathrm{m}^{-3}$, and the exceeding of the National Ambient Air Quality Standard II happened on 34 days (over the standard rate was 73.3\%); on 8 days $(17.8 \%)$, the National Ambient Air Quality Standard III was exceeded.

Recent research showed that the pollution of $\mathrm{NO}_{x}$ caused by vehicle emissions during summer in Beijing is also attracting more attention. The rising of $\mathrm{NO}_{x}$ concentration not only affects the air quality directly but also causes secondary air pollution, an important precursor of ozone. In

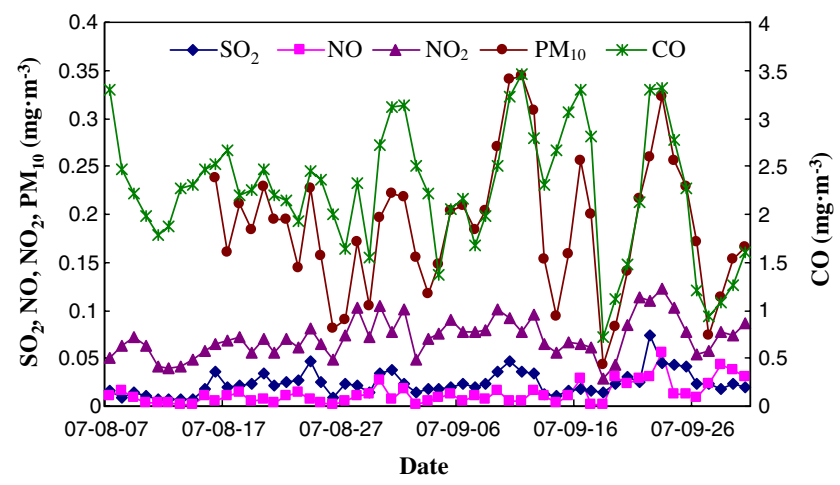

Fig. 2 Daily average concentrations of $\mathrm{SO}_{2}, \mathrm{NO}, \mathrm{NO}_{2}, \mathrm{CO}$, and $\mathrm{PM}_{10}$ in August and September, 2007 recent years, the number of automobiles especially private cars in Beijing has increased sharply at an annual growth rate of 10-20\% over the period (Yao et al. 2003). The total number of vehicles in Beijing was nearly 1.7 million at the end of 2001 (Shrestha et al. 2005) and broke through 3 million by the end of May 2007. Pollution from vehicle emission is becoming more and more serious in Beijing. In contrast, as a result of industrial pollution controls, in recent years, the concentration of $\mathrm{SO}_{2}$ during summer in Beijing has been cut down obviously.

From Fig. 2, the variations of daily average concentrations of $\mathrm{SO}_{2}, \mathrm{NO}_{x}, \mathrm{CO}$, and $\mathrm{PM}_{10}$ are similar, and periodical changes appear during the period of observation. August 28 to September 1, September 9 to 12 , September 15 to 16 , and September 20 to 25 (high-pollution periods) were cloudy and rainy days.

\section{Diurnal variation}

In general, the concentrations of $\mathrm{PM}_{10}, \mathrm{NO}, \mathrm{NO}_{2}$, and $\mathrm{CO}$ were higher at night than during the daytime (Fig. 3). The diurnal variation of $\mathrm{PM}_{10}$ shows double peaks at 7:00-8:00 and 18:00 local time, synchronized with the time of peak traffic. The photochemical reaction activity leads to an obvious decrease of $\mathrm{NO}_{x}\left(\mathrm{NO}\right.$ and $\left.\mathrm{NO}_{2}\right)$ in the daytime. In contrast, the peak value of $\mathrm{O}_{3}$ appears between 11:00 and 18:00 local time (maximum appears at 14:00 local time) when the solar radiation is extremely high in the daytime. Meanwhile, the concentrations of $\mathrm{PM}_{10}, \mathrm{CO}$, and $\mathrm{NO}_{2}$ are affected by meteorological conditions. When the shallow inversion layer appears frequently during urban summer night and the atmosphere boundary layer was stable, air pollutants tend to accumulate in the lower atmospheric layer. The inversion layer is destroyed at sunrise; thereafter, the pollutant concentrations decrease rapidly and remain relative low in the daytime. The concentration of $\mathrm{SO}_{2}$ was more stable, relatively small, and with slightly higher levels in the daytime, which reflects the effort of the control to industrial pollution by the Beijing government. The emission of $\mathrm{SO}_{2}$ in the nonheating period (mainly from few coal-fired power plants) was much less and only impacted near ground level in the daytime when the boundary layer was higher.

Correlation analysis

Based on the correlation analyses, the result showed a good correlation between the daily average concentrations of $\mathrm{CO}$ and $\mathrm{PM}_{10}(r=0.741)$, which suggests that they are also related to the same source-traffic. Incomplete combustion of vehicles would cause the large amount of $\mathrm{CO}$ and particle emissions (Xue et al. 2006). In addition, road dust and the particle from vehicle exhaust are two important 
Table 1 National Ambient Air Quality Standard Levels I, II, and III (GB 3095-1996)

\begin{tabular}{|c|c|c|c|c|}
\hline \multirow[t]{2}{*}{ Pollutants } & \multirow[t]{2}{*}{ Time } & \multicolumn{3}{|c|}{ Concentration $\left(\mathrm{mg} \mathrm{m}^{-3}\right)$} \\
\hline & & Level I & Level II & Level II \\
\hline \multirow{3}{*}{$\mathrm{SO}_{2}$} & Annual average & 0.02 & 0.06 & 0.1 \\
\hline & Daily average & 0.05 & 0.15 & 0.25 \\
\hline & $1 \mathrm{~h}$ average & 0.15 & 0.5 & 0.7 \\
\hline \multirow[t]{3}{*}{$\mathrm{NO}_{2}$} & Annual average & 0.04 & 0.08 & 0.08 \\
\hline & Daily average & 0.08 & $0.12^{\mathrm{a}}$ & 0.12 \\
\hline & $1 \mathrm{~h}$ average & 0.12 & $0.24^{\mathrm{a}}$ & 0.24 \\
\hline \multirow[t]{2}{*}{$\mathrm{CO}$} & Daily average & 4 & 4 & 6 \\
\hline & $1 \mathrm{~h}$ average & 10 & 10 & 20 \\
\hline $\mathrm{O}_{3}$ & $1 \mathrm{~h}$ average & $0.16^{\mathrm{a}}$ & $0.2^{\mathrm{a}}$ & 0.2 \\
\hline \multirow[t]{2}{*}{$\mathrm{PM}_{10}$} & Annual average & 0.04 & 0.1 & 0.15 \\
\hline & Daily average & 0.05 & 0.15 & 0.25 \\
\hline \multirow[t]{2}{*}{ TSP } & Annual average & 0.08 & 0.2 & 0.3 \\
\hline & Daily average & 0.12 & 0.3 & 0.5 \\
\hline
\end{tabular}

${ }^{\text {a }}$ This standard was modified in 2001. The index of $\mathrm{NO}_{x}$ was cancelled. The level II of daily average concentration of $\mathrm{NO}_{2}$ changed from 0.08 to $0.12 \mathrm{mg} \mathrm{m}^{-3} ; 1 \mathrm{~h}$ average concentration level changed from 0.12 to $0.24 \mathrm{mg} \mathrm{m}^{-3}$. 3. One hour average concentration level I of $\mathrm{O}_{3}$ changed from 0.12 to $0.16 \mathrm{mg} \mathrm{m}^{-3}$; level II changed from 0.16 to $0.20 \mathrm{mg} \mathrm{m}^{-3}$.

sources of $\mathrm{PM}_{10}$. Vehicle growth is much faster than the adding of roads, which results in the increase in $\mathrm{CO}$ emission from incomplete combustion of gas during congested traffic and low-speed driving conditions. The correlation between $\mathrm{NO}_{x}$ and $\mathrm{PM}_{10}$ and $\mathrm{CO}$ is not obvious, although $\mathrm{NO}_{x}$ is another vehicle exhaust pollutant. The reason is that the strong activity of photochemical reaction of $\mathrm{NO}_{x}$ makes it easily transform into $\mathrm{NO}_{y}$ or secondary particles by the reactions with $\mathrm{OH}$, oxides, or $\mathrm{NH}_{3}$.

The concentrations of $\mathrm{O}_{3}$ are negatively correlated with $\mathrm{NO}_{x} . \mathrm{NO}_{x}$ is an important precursor of $\mathrm{O}_{3}$ in the daytime, which constantly consumed by the photochemical reactions and produced lots of $\mathrm{O}_{3}$, and the reacting intensity changes with the solar radiation. The peak value of $\mathrm{O}_{3}$ appears at about 14:00 local time. At night, $\mathrm{O}_{3}$ is consumed by the reducing chemical such as $\mathrm{NO}_{x}$ and without any accumulated process, so the concentration of $\mathrm{O}_{3}$ decreases rapidly.

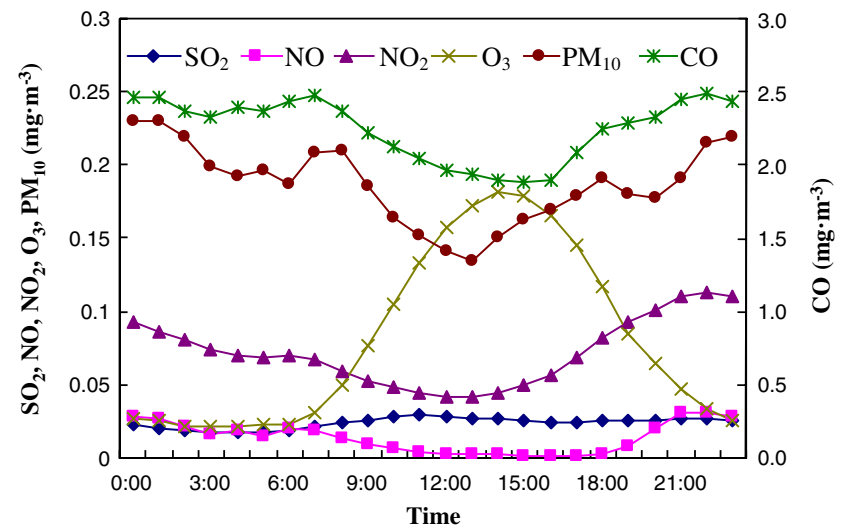

Fig. 3 Diurnal variations of $\mathrm{SO}_{2}, \mathrm{NO}, \mathrm{NO}_{2}, \mathrm{CO}, \mathrm{O}_{3}$, and $\mathrm{PM}_{10}$ in August and September, 2007
The observed ratios of $\left[\mathrm{O}_{3}\right] /\left(\left[\mathrm{NO}_{2}\right] /[\mathrm{NO}]\right)$ are plotted in Fig. 4 (the concentrations are at gas volume fraction $\times 10^{-9}$ ). The ratio remains at low level (below 5) at night, when there is more fresh $\mathrm{NO}$ in air. After sunrise, the ratio of $\left[\mathrm{NO}_{2}\right] /[\mathrm{NO}]$ rises up rapidly. Most parts of $\mathrm{NO}$ are oxidized into $\mathrm{NO}_{2}$; some are transformed into $\mathrm{NO}_{y}$, and the $\mathrm{NO}_{x}$ in the air aged gradually. The peak value of the $\left[\mathrm{NO}_{2}\right] /[\mathrm{NO}]$ ratio (higher than 25) appear at 18:00-19:00 local time, when $\mathrm{NO}_{x}$ is fully aged. Thereafter, the photochemical reaction becomes weaker as the night falls, and the ratio of $\left[\mathrm{NO}_{2}\right] /[\mathrm{NO}]$ decreases rapidly below 5 again as fresh $\mathrm{NO}$ is accumulated in the absence of solar radiation.

The model study results of MM5 and RADM by Yang and $\mathrm{Li}(1999)$ in China show the relationship between $\left[\mathrm{O}_{3}\right]$ and $\left[\mathrm{NO}_{2}\right] /[\mathrm{NO}]$ was linearly connected with the ratio of 15:1 during stable photochemical conditions. However, this condition rarely occurs in the atmosphere, and the actual observation results show that the ratio is always below 15 . For example, the ratio calculated from the observed data in

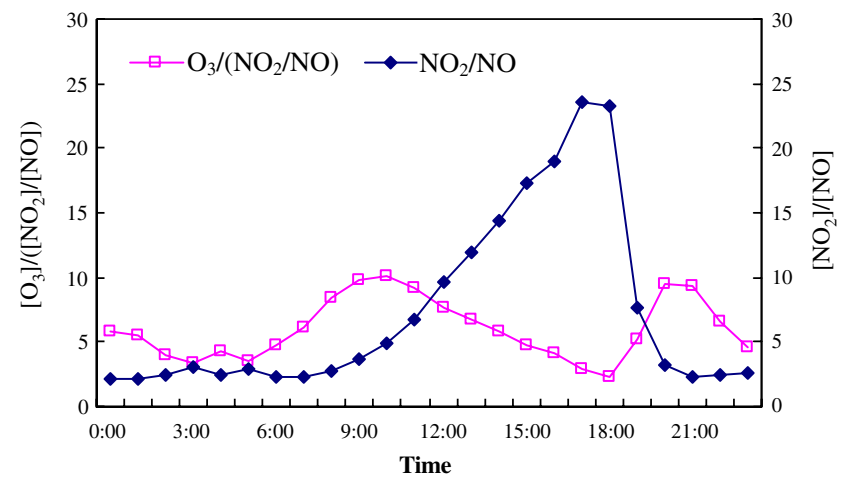

Fig. 4 Ratio of $\mathrm{O}_{3} /\left(\mathrm{NO}_{2} / \mathrm{NO}\right)$ and $\mathrm{NO}_{2} / \mathrm{NO}$ 
Table 2 Emissions of $\mathrm{SO}_{2}$, soot, and industrial dust in Beijing, 2000-2005 (unit: kt)

\begin{tabular}{|c|c|c|c|c|c|c|c|}
\hline \multirow[t]{2}{*}{ Year } & \multicolumn{3}{|l|}{$\mathrm{SO}_{2}$} & \multicolumn{3}{|l|}{ Soot } & \multirow{2}{*}{$\begin{array}{l}\text { Particle } \\
\text { Industry }\end{array}$} \\
\hline & Total & Life & Industry & Total & Life & Industry & \\
\hline 2000 & 223.9 & 77.5 & 146.4 & 100.3 & 48.5 & 51.8 & 93.7 \\
\hline 2001 & 200.7 & 74.4 & 126.3 & 90.3 & 46.5 & 43.8 & 62.7 \\
\hline 2002 & 192 & 71.4 & 120.6 & 80.9 & 47.8 & 33.1 & 46.5 \\
\hline 2003 & 182.8 & 68.8 & 114 & 70.8 & 41.6 & 29.2 & 32.1 \\
\hline 2004 & 191.2 & 65.8 & 125.4 & 70.1 & 41.2 & 28.9 & 35.5 \\
\hline 2005 & 190.6 & 85.1 & 105.5 & 57.6 & 39.9 & 17.7 & 32.5 \\
\hline
\end{tabular}

the lower atmospheric layer in summer, 2000, by Liu et al. (2002) in Beijing was 12.5 on average. The variations of the ratio of $\left[\mathrm{O}_{3}\right] /\left(\left[\mathrm{NO}_{2}\right] /[\mathrm{NO}]\right)$ calculated from the data in this paper are plotted in Fig. 4. The ratio is lower at night and higher in the daytime; the peak value appears at about 10:00 local time, and the daily average value is about 6 because of the high value of $\left[\mathrm{NO}_{2}\right] /[\mathrm{NO}]$ during the highly aged NO in the summer daytime's strong solar radiation.

Emissions and concentration characteristics of pollutions of Beijing in recent years

In mountainous areas surrounding Beijing in all directions except the south, dry air and lack of rain are not favorable for the diffusion and wet deposition of pollutants. Many factories and companies surrounding the city produce significant air emissions. Meanwhile, the growth of car quantity and vehicle emission and lack of adequate control measures make the air pollution more serious. The Beijing municipal government has paid much attention to air pollution, and measures have been taken to address such issues. After several years' efforts by taking measures and policy, the emissions of air pollutants in Beijing have been reduced significantly (Table 2). Figure 5 shows that the concentrations of pollutants have also decreased accordingly, especially the decrease in $\mathrm{CO}$, whose concentration was decreased by $36.4 \%$, from 3.3 (1998) to $2.1 \mathrm{mg} \mathrm{m}^{-3}$ (2006). The concentrations of $\mathrm{SO}_{2}$ and $\mathrm{NO}_{2}$ showed a clear decrease during 1998-2000 and changed slowly later. The concentration of $\mathrm{PM}_{10}$ decreased slowly.

To improve the air quality in Beijing and host the Olympic Games successfully in 2008, a series of control measures have been implemented since the end of 1998 . The source of energy supply has been gradually shifted by using clean fuels and low-sulfur coal. To reduce the local dust emission, the construction activities are supervised by the government, and vegetation coverage of bare ground has been increased. Emission control measures for vehicle exhausts are also adopted such as implementing new emission standards and converting diesel buses to compressed natural gas. Through the effort of environmental protection and the action of "Green Olympics," the Beijing government obtained the "air pollution governance extra prize" and "extension clean automobile award" in "oxygen series award" in France in November 9, 2007. However, compared with some other Olympic cities abroad, such as Helsinki, Los Angeles, Barcelona, and Sydney (Li et al., 2004), Beijing's air quality needs to improve. The Beijing government plans to reduce the emissions and the concentrations of air pollutions by a series of measures, so Beijing will offer good air quality for the Olympic Games in 2008.

\section{Conclusions}

The following are the conclusions from this study:

1. The daily average concentrations of $\mathrm{SO}_{2}$ and $\mathrm{CO}$ during the study period were lower than that of the National Ambient Air Quality Standard II, and the $\mathrm{NO}_{2}$ concentrations basically met the National Ambient Air Quality Standard II. However, $\mathrm{O}_{3}$ and $\mathrm{PM}_{10}$ concentrations were higher than that of the National Ambient Air Quality Standard II.

2. The variations of daily average concentrations of air pollutants showed basically consistency, which might be related closely with source emissions and meteorological conditions.

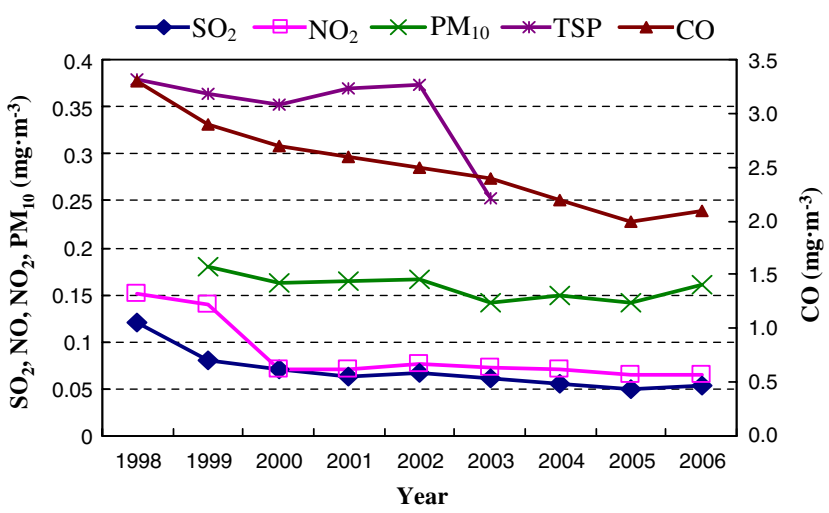

Fig. 5 Variations of annual average concentrations of pollutants in Beijing during 1998-2006 
3. The lowest concentrations of $\mathrm{PM}_{10}, \mathrm{CO}, \mathrm{NO}$, and $\mathrm{NO}_{2}$ appeared at 13:00-14:00; at this time, the atmospheric diffusions are better. The daily variation of $\mathrm{NO}, \mathrm{NO}_{2}$, and $\mathrm{O}_{3}$ agreed with the general roles of photochemical reactions.

Acknowledgments This work was financially supported by Beijing "Air Pollutant transportation and transformation in Beijing and Its Ambient Areas and Its Regulation-Controlling Principles" project (Grant no. HB200504-4).

\section{References}

An X, Zhu T, Wang Z, Li C, Wang Y (2007) A modeling analysis of a heavy air pollution epiosde occured in Beijing. Atmos Chem Phys 7:3103-3114

He K, Yang F, Ma Y, Zhang Q, Yao X, Chan CK, Cadle S, Chan T, Mulawa P (2001) The characteristics of $\mathrm{PM}_{2.5}$ in Beijing, China. Atmos Environ 38:4959-4970

John W, Wall SM, Ondo JL, Winklmayr W (1990) Models in the size distributions of atmospheric inorganic aerosol. Atmos Environ 24A:2349-2359

Jraiw K (2002) Cleaning the air: Vehicular emission in the People Republic of China (PRC). ADB 35th Annual Meeting, 12 May, Shanghai International Convention Center, PRC. Available at: http:/ www.adb.org/AnnualMeeting/2002/media/vehicle_emissions.asp

Li J, Xiao Z, Yang S, Shao L (2004) Analysis of pollution characteristics of inhalable particulate matter in Beijing and a comparison with some other Olympic Games cities. Environ Sci Trends 3:26-28 (in Chinese)

Liu F, Chen H, Liu Y (2002) Study on the vertical observations of $\mathrm{NOx}$ and $\mathrm{O}_{3}$ in the low level of ABL in Beijing area. J Ocean Univ Qingdao 32(2):179-185 (in Chinese)

Lun X, Zhang X, Mu Y, Nang A, Jiang G (2003) Size fractionated speciation of sulfate and nitrate in airborne particulates in Beijing, China. Atmos Environ 37:2581-2588

Okuda T, Kato J, Mori J, Tenmoku M, Suda Y, Tanaka S, He K, Ma Y, Yang F, Yu X, Duan F, Lei Y (2004) Daily concentrations of trace metals in aerosols in Beijing, China, determined by using inductively coupled plasma mass spectrometry equipped with laser ablation analysis, and source identification of aerosols. Sci Total Environ 330(1/3):145-158

Shrestha RM, Anandarajah G, Adhikari S, Jiang K, Zhu S (2005) Energy and environmental implications of NOx emission reduction from the transport sector of Beijing: a least-cost planning analysis. Transp Res Part D Transp Environ 10:1-11

Song Y, Zhang Y, Xie S et al (2006) Source apportionment of $\mathrm{PM}_{2.5}$ in Beijing by positive matrix factorization. Atmos Environ 40:1526-1537

Sun Y, Zhuang G, Wang Y, Han L, Guo J, Dan M, Zhang W, Wang Z, Hao Z (2004) The air-borne particulate pollution in Beijingconcentration, composition, distribution and sources. Atmos Environ 38:5991-6004

Vesilind PA (1982) Environmental pollution and control. Ann Arbor Science, Ann Arbor, MI

Xue M, Wang Y, Sun Y, Hu B, Wang M (2006) Measurement on the atmospheric $\mathrm{CO}$ concentration in Beijing. Environ Sci 27 (2):200-206 (in Chinese)

Yan P, Huang J (2002) A preliminary study of effects of surrounding sources on surface $\mathrm{SO}_{2}$ in Beijing. J Appl Meteorol Sci 13 (Suppl):144-152 (in Chinese)

Yang X, Li X (1999) A numerical study of photochemical reaction mechanism of ozone variation in surface layer. Chin J Atmos Sci 23(4):427-438 (in Chinese)

Yao XH, Chan CK, Fang M, Cadle S, Chan T, Mulawa P, He K, Ye B (2002) The water-soluble ionic composition of $\mathrm{PM}_{2.5}$ in Shanghai and Beijing, China. Atmos Environ 36:4223-4234

Yao XH, Lau AP, Fang M, Chan CK, Hu M (2003) Size distributions and formation of ionic species in atmospheric particulate pollutants in Beijing, China: inorganic ions. Atmos Environ 37:2991-3000

Zhang J, Song H, Tong S, Li L, Liu B, Wang L (2000) Ambient sulfate concentration and chronic disease mortality in Beijing. Sci Total Environ 262:63-71

Zhang R, Cai X, Song Y (2004) Spatial-temporal variation and accumulation effect of air pollutants over Beijing area. Acta Sci Nat Univ Pekinensis 40(6):930-938 (in Chinese)

Zhang K, Wang Y, Wen T, Meslmani Y, Murray F (2007) Properties of nitrate, sulfate and ammonium in typical polluted atmospheric aerosols $\left(\mathrm{PM}_{10}\right)$ in Beijing. Atmos Res 84:67-77 